\title{
IMPROVEMENT OF RISK MANAGEMENT PRINCIPLES IN OCCUPATIONAL HEALTH AND SAFETY
}

Purpose. To improve the risk management principles in occupational health and safety.

Methodology. In study the following set of scientific methods was used: analysis of scientific and technical literature and international normative legal documents on the construction and operation of occupational health and safety management systems; probabilistic-statistical methods; the theory of Markov processes; methods of formalization.

Findings. The main problems that make it impossible to objectively implement the PDCA process in modern occupational health and safety management systems in organizations are identified. It is noted that the identified problems are related to: uncertainty of the requirements of ISO 45001:2018 regarding the purposes, sequence and results of each procedure of the PDCA process in occupational health and safety; inadequacy of methodological support of the main stages of the Plan procedure; lack of practical opportunities for objective implementation of Do, Check, Act procedures. The prerequisites are established for the transition of the systems of health care (HC) and occupational safety support (OSS) to the new concept of proactive risk management (based on the operation of two small cycles within the PDCA process), which allows ensuring the existence of objective relationships between all procedures of the PDCA process; increasing the efficiency of the HC and OSS systems through providing the ability to manage the impact of negative factors on the employee by certain parameters; determination of clear cause and effect relationships between the parameters of the impact of negative factors on the employee and the incident, as well as other benefits. The possibility of application of the automated system of complex protection of employees from occupational dangers was substantiated to solve practical problems of the new concept of PDCA in the HC and OSS systems in the organizations.

Originality. For the first time, the concept of proactive risk management based on the principles of small cycles in the PDCA process was substantiated and proposed for use in the HC and OSS systems.

Practical value. The obtained results will be used for development of projects of changes in the maintenance and structure of the international standards ISO 45001:2018, IEC/ISO 31010:2019, ISO 31000:2018.

Keywords: occupational health and safety, Schuhart-Deming cycle, risk management, ISO 45001:2018

Introduction. Ensuring comfortable, healthy and safe working conditions at enterprises, institutions and organizations (hereinafter organizations) always requires the development, implementation and continuous improvement of a set of organizational, technical, socio-economic, legal and treatment and prevention activities and means. It is obvious that all the necessary actions for the development, implementation and continuous improvement of activities and means in occupational health and safety should be as clear as possible for the responsible person, as well as organized in a certain system health care (HC) and occupational safety support (OSS) management, which has an appropriate legal framework. At present, OHSAS series standards as the specified international legal framework, whose development at one time removed the current problems in the field of international economic cooperation, which were associated with the lack of uniform standardization of HC and OSS systems in organizations around the world, are used [1].

However, despite the progressivity of development idea, OHSAS standards do not contain a clear algorithm concerning the development of HC and OSS systems in the organization, being limited to general recommendations that such a system should be based on the Schuhart-Deming cycle (PDCA process) [2]. The general nature of the structure and content of OHSAS standards has identified the need to develop additional standards (ISO series), which already contain recommendations for the selection and application of defined nomenclature of certain methods to implement some procedures (but not all) of the PDCA process. But again, these recommendations are limited only by the nomenclature, general description and cautions about the using and necessity of combining these or other methods [2].

Thus, today there is a situation where the certification of $\mathrm{HC}$ and OSS systems for OHSAS standards in organizations does not lead to an improvement in occupational health and safety in practice, as it is pro forma. This is due to the fact that within the existing legal framework the basic procedures of the

(C) Bochkovskyi A., 2020
PDCA process are either impossible to implement (due to the lack of methods for implementing certain stages of procedures and other reasons), or can be implemented only formally (using methods based not on the principle of objectivity of the obtained results, but on the principle of selecting the easiest to use) [2]. By the way, as a rule, OHSAS enterprise certification specialists are trained according to the latter principle.

Another very important defect of the relevant legal framework is the fact that the ISO supporting standards (as opposed to OHSAS) are intended to a wide range of applications (including financial, environmental and other risk management) and are not intended directly to occupational health and safety. That is, the methodological support provided in them does not take into account some important nuances related to the identification of dangerous, harmful production and other negative factors, evaluation of their negative impact on the employee, the setting of criteria for such evaluation, and others.

In order to improve the normative legal support of $\mathrm{HC}$ and OSS systems, a new generation standard - ISO 45001:2018 (replaced OHSAS), as well as a number of evaluation standards (IEC/ISO 31010:2019) and risk management (ISO 31000:2018) were developed by the International Organization for Standardization (ISO) [3, 4]. At the same time, the developers underline the fact that the basis of the new legal framework is, respectively, the standards OHSAS, IEC/ISO 31010 and ISO 31000 of the first editions (2009) [4]. With this in mind, there is a threat of non-consideration of certain defects that has characterized previous standards in the content of the new legal framework by developers, and also the occurrence of new ones (including derivatives of previous ones), which can significantly affect the quality of HC and OSS systems. Identifying these defects will substantiate and suggest solutions and, given that ISO 45001:2018 should replace the OHSAS standard only within the next three years, will anticipate appropriate changes to its content and structure, as well as the content and structure of IEC/ISO 31010:2019 and ISO 31000:2018 [3].

Literature review. The issue of improving the principles of functioning of the Schuhart-Demng cycle in occupational 
health and safety was considered in the following studies [510]. However, the analysis of these studies revealed the following number of unsolved problems and defects.

Thus, in [5], based on the analysis of the requirements of ISO 45001:2018, a model of operational monitoring was proposed for HC and OSS systems, in order to improve the Do procedure of the PDCA process. The study concept is to develop a decision-making algorithm by a person in charge when controlling the operational parameters of the test system, according to the set risk evaluation criteria. However, it is unclear how and by what means the person in charge can influence the operational parameters if they do not meet the set criteria.

In addition, given the need for an expert approach to determine both the parameters and the evaluation criteria of their characteristics, the results of the relevant procedure and process as a whole cannot be considered objective.

The study [6] is focused on exploring the impact of individual processes occurring in the functioning of the SchuhartDeming cycle on the level of occupational safety of employees, based on the use of fuzzy cognitive maps (FCM). According to the results of the study, a model consisting of 16 objects, one of which corresponds to a certain indicator of occupational safety, and the rest - to the parameters of processes (within which the indicator is affected) was constructed. It is established that the most important influence on the level of occupational safety is caused by the parameters related to making certain decisions by a person (a leaders of the organization). The obtained results prove the significant role of the influence of "human factor" signs among other potential negative factors on the state of safety of the "man - machine - environment" system. However, no practical recommendations were given in the study for the possibility of managing by such factors within the functioning of the cycle, which will result in increased safety of employees.

The study [7] is devoted to the analysis of the requirements of ISO 45001:2018, in terms of the need to prevent accidents at work. The causation in the context of the legal and methodological support of the Schuhart-Deming cycle in occupational health and safety, as well as other aspects that affect the employee's occupational safety level was considered. However, there are no precise conclusions regarding understanding of these causation.

Based on the results of the analysis of the causes of occupational dangers (in Spain) as well as the content and structure of ISO 45001:2018 [8], the causation between the causes of dangers and improper compliance (non-compliance) of a certain standard requirements was found. It is noted that the greatest number of errors occurs at the risk evaluation stage as determining (in the author's opinion), which influences the results of the functioning of the Schuhart-Deming cycle. Concurring in general with the author's thesis on the importance of the impact of risk evaluation results on the PDCA process results, the following main defects of the study should be provided: lack of focus on the causes of these errors, which are always associated with the features of the evaluation (the right selection of method, its objectivity, and so on) and lack of focus on the need to consider the evaluation in the context of its relationships with other PDCA stages and procedures (the principle of systematic approach).

In the study [9], the features of the principles of functioning of the Schuhart-Deming cycle in HC and OSS systems in different countries were analyzed. The advantages and disadvantages of different approaches (methodological and practical ones) to ensure safe, healthy and comfortable working conditions in the cycle procedures were identified. It was found that the key to the effective implementation of the SchuhartDeming cycle is the need to ensure clear and objective relationships between its procedures. Although no conclusions and recommendations about the progressivity one approach or other to the implementation of relevant procedures were given in the study, its results are a useful analytical basis for justifying the need and identifying ways to improve the existing concept of PDCA in occupational health and safety.

The analysis [10] of the main indicators of employees' occupational safety level (occupational injuries and diseases) in more than 5,000 companies in Spain showed that the certification of companies for the OHSAS standard has almost no effect on level improvement. In addition, it was found that in certain areas of activity (financial and others) this certification had a negative effect. It was concluded that the existing concept of the PDCA process in occupational health and safety is ineffective and that it is necessary to develop means to improve it. But in the study precise ways of development and implementation of these means are not given.

Purpose. To improve the principles of risk management in occupational health and safety.

Achieving this purpose is expected when solving the following tasks:

- to identify the main problems of implementation of PDCA process procedures and ways of their solution based on the analysis of the content and structure of ISO 45001:2018;

- to conduct a critical analysis of the existing methodological support for the Plan procedure stages in accordance with the recommendations of IEC/ISO 31010:2019 and ISO 31000:2018;

- to improve the methodological support of the IEC/ISO 31010:2019 standard for the possibility of objective implementation of the Plan procedure stages of determining of resources and risk evaluation;

- to substantiate and to propose for occupational health and safety an improved concept of the PDCA process based on the operation of small cycles;

- to identify the main problems of practical implementation of the new concept and to suggest ways and practical possibilities for their solution.

Results. The ISO 45001:2018 standard is positioned by the developers as a guideline for the implementation and operation of $\mathrm{OH} \& \mathrm{~S}$ systems in organizations and for verification the compliance of existing $\mathrm{HC}$ and OSS systems with its requirements [11]. As ISO is a global federation of national standardization bodies, this document (unlike OHSAS, which was originally created as a national standard) can reasonably be considered the first international standard that set uniform legal requirements for the development and operation of $\mathrm{HC}$ and OSS systems in the international format. This, in turn, requires from the content and structure of the document comprehensive information on the specification and sequence of relevant actions for the executor (responsible person, occupational health and safety service).

According to the requirements of ISO 45001:2018, the development and operation of HC and OSS systems in organizations is carried out under the PDCA process, which involves consistent and cyclical implementation of the following procedures: planning (Plan) - implementation (Do) - monitoring (Check) - correction (Act).

Methodologically, the implementation of the first procedure - Plan - involves three consistent stages, namely the identification of dangers, risk evaluation and evaluation of opportunities in $\mathrm{HC}$ and OSS systems (the order of sequence and names of stages are given in par. 6.1.2) [11]. However, before analysis of these stages, it is necessary to make the following general points.

The first of them is the term - "dangers identification" [11]. According to par. 3.19, "danger" is interpreted as a source that may be a potential cause of occupational injury or illhealth of the employee $[2,11]$. Such sources within the "man - machine - environment" systems are dangerous and harmful production factors (DHPF), dangerous human actions or inaction, groups of people ("human factor" signs), as well as environmental factors that have a negative impact on the employee (all together - negative factors or NF) [2]. This point is 
important because further risk evaluation and identification of opportunities in $\mathrm{OH} \& \mathrm{~S}$ systems should be carried out separately for each identified NF, and not as a group [2]. Therefore, as a stage name it is more correct to use "identification of negative factors" instead of "dangers identification".

The second point is the term "identification of opportunities in HC and OSS systems", which according to par. 3.22 is interpreted as a set of circumstances that may lead to improved indicators of HC and OSS systems [11]. Such indicators are indicators of occupational injuries, occupational diseases, and so on (par. 3.28) [11]. Accordingly, these circumstances should be understood as a set of organizational, technical, legal, preventive and socio-economic activities and means of occupational health and safety, which are developed and implemented by the organization within HC and OSS systems. Qualitative and quantitative characteristics of these activities and means depend on the financial capabilities of the organization. Therefore, for this stage it is more correct and clear to use "determining of resources for occupational health and safety" ("determination of resources").

According to par. 6.1.2.1, the NF identification should be carried out constantly and actively [11]. Within this process, the workplace is considered in terms of compliance with the requirements of regulations, compliance with set regimes of work and rest, the possibility of emergencies, the impact of "human factor" signs and other aspects on the safety of the production process [11]. In general, the term "identification" means the recognition of potential NF at the object of study (workplace) by comparing their characteristics with a certain criterion [2]. The NF classified in the relevant legal document should act as such a criterion [2]. However, the requirements of par. 6.1.2.1 are limited to a list of aspects and circumstances that need to be addressed during identification. The ISO 45001:2018 does not contain any nomenclature of classified NF or normative references to another document where such a nomenclature is defined. This is a serious problem, as each classified NF must be associated with a certain normalized value, which is a criterion for further evaluation of the risk level of occupational dangers [2]. According to par. 6.1.2.2, the organization must conduct evaluation of these risks (within the relevant stage) for each identified NF, taking into account the effectiveness of existing activities and means of occupational health and safety (par. 6.1.2.2 (a)) [11]. Risk evaluation should be conducted by methods and criteria that are determined taking into account their area, nature and time of application [11]. Given the uninformativeness of par. 6.1.2.2, it is obvious that when selecting an evaluation method, the organization should use other standards that contain the necessary methodological support [11].

In the absence of normative references to the required standards in ISO 45001:2018, the implementor should decide independently on the use of a supporting standard, which in turn causes new problems related to the need to justify the selection of methods, their combination, the existence of appropriate competencies to perform such actions and other problems [2]. A specific problem of the risk evaluation stage is the definition of evaluation criteria. As indicated earlier, according to the requirements of par. 6.1.2.2, the organization should determine such criteria itself [11]. Given that the risk evaluation is performed separately for each identified $\mathrm{NF}$, then the criteria for such an evaluation should be related to the normative value of the identified NF. However, as the standard is limited to the requirement to independent setting evaluation criteria by the organization itself, there is a need to either develop appropriate supplement to ISO 45001:2018, or the selection by organization of the evaluation method that takes into account this relationship. In the latter case, the task of risk evaluation for a certain identified NF can be formulated as the probability of not exceeding the accumulation of negative impact from such a factor to the set (normative) value $\sigma$

$$
\left.\lim _{t \rightarrow \infty} P\{\xi(t)) \leq \sigma\right\}>1-r
$$

where $r$ is the set value (criterion) of risk; $\xi(\mathrm{t})$ is accumulation level of the negative impact from the negative factor in the employee at time $t$.

The next stage - determining of resources - is methodologically undefined and, accordingly, unsecured in the standard ISO 45001:2018. However, based on the requirements for planning the achievement of purposes in occupational health and safety (in particular, ensuring the relationship between par. 6.2.1. (c) and par. 6.2.2 (b)), within this stage it is necessary to set the relationship between the capabilities (resources) of the organization for occupational health and safety and the risk level of occupational dangers (hereinafter risk) $[2,11,12]$. Based on this, the key task of this stage is to find the relationship between the set resources and the acceptable risk level for the organization. In this case (based on par. 3.15 and 3.17) the acceptable risk level should be understood as the maximum occupational safety level that organization can provide by developing, implementing and ensuring the set of occupational safety means within its financial capabilities [12]. Thus, this task can be presented as determination of the minimum possible risk level, non-exceedance of which the organization can provide within the allocated resources for occupational health and safety. Also, another task can be formulated - to determine the minimum resources in limiting certain risk level [12]. It should be noted that consideration of the inequality (1) is also relevant for the above tasks. However, an important problem in solving the set tasks is the lack of any normative references to other standards or literature that advise or contain methodological support for finding the required relationships in the content of ISO 45001:2018. To make objective planning of $\mathrm{HC}$ and OSS systems possible, the organization should have methodological support that allows determining objectively the required resources for activities and means in occupational health and safety. This stage is very important in the PDCA process since ensuring the objectivity of the results is defined by the requirements of par. 03 (e) as one of the key factors for effective functioning of $\mathrm{HC}$ and OSS systems for setting the required resources for occupational health and safety [11]. Regarding the need to implement the tasks of the resource determination stage and some requirements of the risk evaluation stage (paragraph 6.1.2.2 (a)), another methodological problem should be solved, which concerns the sequence of their implementation according to the structure of par. 6.1.2 [11]. The point is that the sequence of implementation of the Plan procedure at all stages should provide for a clear relationship between the previous stage results and the input data of the next one. Thus, the identification stage is unequivocally primary, since the nomenclature of identified NF is the basis (input) for risk evaluation and determination of resources, the sequence of the other two stages (as in par. 6.1.2) is controversial [11]. That is because the evaluation stage, which is before the stage of determination of resources, provides conducting the risk evaluation taking into account the effectiveness of the envisaged activities and means in occupational health and safety (par. 6.1.2.2 (a)) [11]. But the qualitative and quantitative characteristics of such activities and means are determined based on the capabilities of the organization. Therefore, the following sequence of the Plan procedure stages is logical: NF identification - determination of resources - risk evaluation.

Within the Do procedure (following the Plan), the organization should plan and apply the processes required to implement the results of the Plan procedure, as well as to manage these processes and maintain them (par. 8.1.1) [11]. These requirements are aimed at the main task of implementing the procedure - prevention of occupational dangers (par. 8.1.2), as well as industrial accidents and catastrophes (par. 8.2) [11]. Implementation of this task involves introduction and provi- 
ding of functioning of the planned activities and means in occupational health and safety, and also management of changes in the parameters influencing employees' occupational safety level (par. 8.1.2, 8.1.3, 3.28) [11]. Thus, in meeting the requirements of par. 8.1.2, 8.1.3 and 8.2 the main task of the Do procedure can be represented as the task of managing the parameters of the NF impact within the set values, by implementing and providing the functioning of activities and means in occupational health and safety [11]. It is clear that the values of manageable parameters, as well as qualitative and quantitative characteristics of these activities and means should be set based on the Plan procedure, and the practical implementation of this task should be conducted within the next procedures - Check and Act.

According to par. 9.1.1 the next procedure of the PDCA process - monitoring (Check) - is characterized by the need to measure the levels of impact of harmful production factors on employees, tracking incidents of occupational injuries and ill health, collection of information about the employee's competence level in occupational health and safety, analysis of normative legal documents relating to $\mathrm{HC}$ and OSS systems and other means [11]. In standards it is considered that the monitoring can be conducted regularly in the form of constant control, supervision, critical analysis, and others [11]. In this case, the word "can" defines a dual characteristic of the monitoring procedure: as periodic, carried out by irregularly (no time characteristics for the implementation periods is in standard) and as permanent (regularly), which is incorrect. Given that the parameters of the NF impact on the employee are random and dynamic, the order of monitoring procedure should be defined unequivocally, namely, as regular and, possibly, continuously.

The last procedure of the PDCA process - correction or improvement (Act) involves the corrective actions, innovative solutions, critical changes, continuous improvement of the organization in occupational health and safety, reorganization of the enterprise or its elements, and so on (par. 10.1) [11]. These actions should be applied either in case of an incident or in case inconsistency between the manageable parameters values and the monitoring results (par. 10.2) [11]. After that the organization is invited to apply (timely) certain corrective actions (par. 10.2) [11]. In this case, given that the monitoring results should be the values of the parameters of the NF impact, whose real characteristics are random and dynamic, the corrective action should be conducted timely and quickly.

Therefore, the objective implementation of the Check and Act procedures involves the use of certain practical opportunities for continuous monitoring and prompt correction of the managed parameter values according to a certain nomenclature of identified NF within the limits on the results of the Plan procedure. This will allow objectively ensuring the solution of the main task of the Do procedure, which concerns the prevention of occupational dangers within "man - machine environment" systems. However, the problem of objective implementation of these procedures is the lack of any requirements or recommendations under ISO 45001:2018 concerning how and with what methodological support the organization should determine the managed parameters value during the Plan procedure. And also, how and by what activities and means the organization should conduct such parameter management. Accordingly, the solution to these problems is towards determining the methodological support for the objective implementation of each of the Plan procedure stages and providing practical opportunities for the implementation of the Do-Check-Act procedures.

As noted, the Plan procedure methodologically involves three main stages: potential NF identification, determining of resources for occupational health and safety and risk evaluation of occupational dangers. In the absence of any normative references to ancillary standards in ISO 45001:2018 (par. 2), in which necessary methodological support for the imple- mentation of certain stages could be chosen, only standards corresponding ISO series should be used. Such normative legal documents are the current IEC/ISO 31010:2019 and ISO 31000:2018, which can be used in occupational health and safety, yet are not intended for it directly (par. 6.3) [13]. At the same time, the requirements of ISO 31000:2018 regarding the structure and order of implementation of the PDCA process are similar to the requirements of ISO 45001:2018, and IEC/ ISO 31010:2019 is intended to implement the Plan procedure stages of the PDCA Process. This allows using the methodological support provided in the IEC/ISO 31010:2019 standard to implement the relevant procedure ISO 45001:2018. According to the recommendations of IEC 31010:2019 for identification stage, the organization is proposed to select one of the twenty-eight methods, which are divided by two main criteria: A (applicable) and SA (strongly applicable) [14]. In fact, the methods related to the SA criterion are priority. From the presented nomenclature of identification methods, the standard recommends the use of the following methods related to the SA criterion, namely: "Brainstorming", "Checklists", "Scenario analysis", "Delphi technique", "SWIFT" [14]. Methodologically, the identification stage is not complicated; any of the recommended methods is in principle understandable to implementation and does not require improvement [2]. But, given that they all belong to expert methods, the objectivity of the results in their use directly depends on the level of implementor competence, in particular in occupational health and safety ("human factor" signs) and the quality of ancillary normative legal support [2]. To decrease the errors related to the impact of the "human factor" signs and to increase the level of objectivity of the results, a group of implementors, which includes members of all structural units of the organization is proposed to involve to implementation this stage by the requirements of ISO 45001:2018 (p. 5). In addition, recognizing a priori the possible erroneousness of the obtained identification results, to use the standard EN 12973 (par. B.1.1) is proposed (during identification) by the recommendations of IEC 31010:2019 [14]. The focus of the developers of IEC 31010:2019 on the problem of minimizing the impact of the "human factor" signs is an important means to improve both the objectivity of the identification results and the quality of the content of the standard itself. However, this is negated by the existence of the following two main problems, which are directly related to the quality of other ancillary normative legal support of identification stage, without which its implementation is impossible.

The first of them is due to the fact that methodologically the identification stage of potential NF within the normative legal documents of the ISO series is not based on the need to equate the identified factors with the nomenclature classified in the relevant standards (par. 6.3.2 and par. B.1.1) [11]. According to the requirements, experts will make a list of potential dangers, based on their own knowledge and experience, taking into account all activities and means of occupational health and safety at each workplace [14]. This approach is based on the "depersonalization" of NF, which, as a consequence, does not allow setting a relationship with the nomenclature of these factors for which the normalized values are defined by law. Thus, it becomes impossible to implement all other procedures of the PDCA process; in particular, setting objective criteria of risk evaluation, monitoring parameters and correcting the NF impact on the employee, and so on become unclear. The existence of this problem is explained, to some extent, by the lack of the standards in which the nomenclature of NF is classified in normative legal frameworks in most countries (including the EU). But at the same time, some EU countries solve this problem within the international cooperation with the ILO (International Labor Organization) by developing practical guidelines for risk evaluation. For example, according to the recommendations of a practical guideline for workplace risk evaluation developed by the ILO 
and the Department of Occupational Safety and Health of the Ministry of Social Security and Health of Finland (author M. Murtonen), the identification stage is based on the "Checklists" method, which provides for formulation checklists, into which the list of the full nomenclature of NF is previously included.

This nomenclature includes a group of physical factors $(\mathrm{F})$, which combines 12 names of NF $(\mathrm{F} 1-\mathrm{F} 12)$, respectively, a group of risk factors for accidents (T1 - T22), ergonomic factors (E1 - E20), chemical (K1 - K18) and biological danger (B1 - B2), psychological pressure (H1 - H19). Relevant recommendations for the implementation of the identification stage exist in other EU countries [15]. The second problem of normative legal support of the identification stage is related to the fact that to date the necessary normalized values are set for not all potential NF by national legislation. For example, in Finland, only $14.4 \%$ of group F, T, E, K, B and H factors are regulated among all nomenclature of classified NF by the relevant EU Directives and national legislation (50\% of group F factors, $0.5 \%$ of group $\mathrm{E}$ factors and $22 \%$ of group $\mathrm{K}$ factors, group $\mathrm{T}$ and $\mathrm{H}$ factors are not regulated at all) (Figs. 1, 2) [16]. The situation is almost similar in other EU countries [17].

This is partly due to the impossibility of objective (instrumental) determination of normalized values for certain groups' factors. However, even for NF that are to be measured instrumentally (within certain groups), not each of them is normalized. For example, for the nomenclature of organic harmful substances (group K) set by the EU Directives, the normalized values (by two required norms, i. e. maximum single and average concentrations) are defined for only $53 \%$ of substances. For about $4 \%$ of substances, only average concentrations are determined, for the remaining set substances only maximum single concentrations are determined [18, 19].

These values correlate to the results of research by M. M. Korshun (Committee on Hygienic Regulation of the Ministry of Health of Ukraine). The issues of developing standards for factors of the psychophysiological group, certain physical, chemical, biological factors, etc. also remain open. This problem is global without exaggeration, and belongs not only to occupational health and safety, but also to the legal, the occupational medicine and others. Thus, the solution of these problems is both strengthening international cooperation between ISO and ILO and strengthening cooperation of national ISO agencies with the legislatures of the respective countries in order to develop and improve the necessary ancillary normative legal acts on classification and normalization of NF.

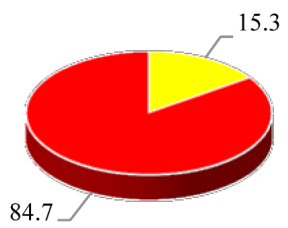

Fig. 1. The proportion of classified NF for which the normalized values are set

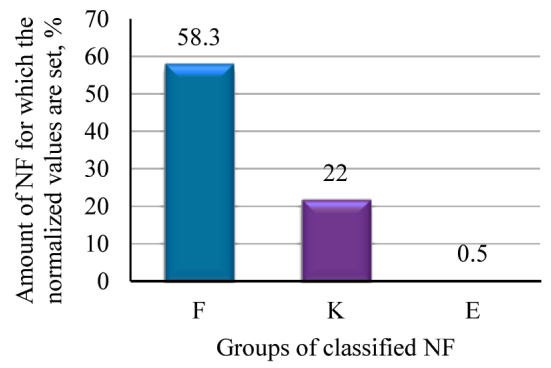

Fig. 2. Provision the classified NF by normalized values (by groups)
The next stage of the Plan procedure is to determine the resources for occupational health and safety. This involves setting reasonable relationships between the risk level acceptable to the organization and resources that will provide opportunities for not exceeding it. Thus, the methodological support of this stage (given the need to determine the risk level) should also be contained in the standard IEC 31010:2019. However, at this stage, the implementor faces the lack of not only the selection of the appropriate method from tables A2 and A3 in IEC 31010:2019, but also any mentioning about this stage in the standard. The situation is similar for another auxiliary standard ISO 31000:2018. Thus, it should be noted that this stage within ISO series standards is methodologically unsecured.

The implementation of the next stage - risk evaluation is complicated in legal terms due to certain inconsistency between the content of the standards ISO 45001:2018 and IEC 31010:2019. The fact is that under ISO 45001:2018, the identification of NF is considered as a separate stage of the Plan procedure, which includes the evaluation stage also. The structure of IEC 31010:2019 considers risk evaluation not as a stage within the Plan procedure, but as a separate process that involves the stages of identification, risk analysis, their criterion evaluation, and so on. This is not a mistake, but causes confusion in the practical aspects of applying the methodological support IEC 31010:2019 to implement the requirements of ISO 45001:2018. Therefore, given that IEC 31010:2019 is as an auxiliary standard in this case, to apply the sequence of stages according to the standard ISO 45001:2018 is appropriate, i. e. the identification stage should be considered as priority. Thus, the risk evaluation stage will consist of two main sub-stages. The first - Risk analysis - involves determining the probability of a negative impact of previously identified NF on the employee, analyzing the severity of the consequences of such impact, quantitative risk level evaluation. The second (Risk evaluation) - involves comparing the obtained quantitative results with certain criteria [14]. Moreover, the sub-stage Risk analysis involves taking into account the effectiveness of existing activities and means of occupational health and safety, while the sub-stage Risk evaluation involves setting evaluation criteria that correlate with the requirements of ISO 45001:2018 (par. 6.1.2.2). As shown, the requirements of IEC 31010:2019 regarding the order and results of risk evaluation do not differ from the corresponding requirements of the first edition standard $[2,14]$. The order for selecting and combining evaluation methods (according to Appendix A, Tables A.2 and A.3) are also similar [2, 14]. Since the issue of selecting and combining methods for all evaluation sub-stages was analyzed in a previous study, it is necessary to focus on the practical possibilities and effectiveness of their application to meet the requirements of ISO 45001:2018 [2]. As noted, one of the main criteria for selecting the method is the so-called criteria A and SA (the latter is a priority). To implement the sub-step Risk analysis, 19 methods which correspond to both criteria are proposed to use by the standard IEC 31010:2019. Moreover, each of these methods involves the implementation of this sub-step comprehensively, i.e. does not require combination with other methods, which significantly increases the objectivity of the results and usability [2]. Technically, the standard proposes (for Risk analysis) a much larger number of methods, which should not be considered as an alternative due to the need to combine them, justify the possibility of such a combination and other problems that significantly reduce the effectiveness of their use [2]. Given the priority of the SA criterion, the selection of methods decreases up to 3 from 19, namely - "Failure modes and effects and criticality analysis", "Toxicological risk assessment" and "Human reliability analysis" [14]. The first is for critical risk analysis associated with the corresponding failures of technical systems. The main defect of the method is in the name, i.e. its application in occupational health and safety is actually limited by analysis of risks of occupational injury by the employee, due to the impact of certain dangerous produc- 
tion factors during a sudden equipment failure. Therefore, it cannot be used to analyze the risks associated with the negative impact of harmful production factors (HPF) on the employee. This limitation is a serious defect that does not allow use for the vast majority of occupations related to both headwork, which proportion is increased every year by an average of $15-$ $20 \%$, and harmful working conditions [1, 12]. And this despite the fact that the number of fatality from the effects of harmful production factors is almost 7 times higher than the fatality from occupational injuries [1, 12]. That is, the field of application of this method in practice is very limited and essentially conflicts with one of the main principles of selecting evaluation methods - the complexity of application. The next method "Toxicological risk evaluation" is also narrowly focused, but is intended, on the contrary, to risks analysis associated with the negative impact of HPF on the employee. The essence of the method is to set the relationship between the impact level of a certain HPF and the harm level from such impact. The method is based on data that should be obtained by experimental way. This is the first defect as such data for the field of occupational health and safety are very limited. In addition, the method is limited for the evaluation of physical group HPF (industrial noise, vibration and other factors); this is the second defect. The third and main defect of the method is its static nature, as the risk level for the employee is determined for certain concentrations of HPF. This approach does not correspond to the real conditions, when a certain HPF affects an employee during the work shift, at random periods of time and with random intensity and the consequences of such impact accumulate in the body. And after working hours the consequences of the negative impact of HPF are excreted from the body. In addition, this method also conflicts with the principle of approach complexity to risk evaluation, as it can be applied only to risks associated with occupational diseases or poisonings. The last of the methods recommended by the comprehensive SA criterion "Human reliability analysis" is aimed at analysis potential errors of the operator of technical systems, which can result in occupational dangers (usually occupational injuries), or industrial accidents or catastrophes. This method has both the defects of the two previous methods (limitation to analysis the negative factors) and their own ones, the main of which is lack of objectivity (dependence of the results on expert opinions). Despite the fact that the influence of the "human factor" signs is the main cause of occupational dangers, precisely the subjectivity of the method eliminates the practical value of the results almost completely.

To implement the next sub-stage Risk evaluation, 24 methods on the A and SA criteria or 16 methods exclusively on the SA criterion are proposed to use. However, given the need to apply the principle of complexity of the evaluation, methods that meet the criterion of SA (for both Risk analysis, and Risk evaluation) is priority. These are the "Failure modes and effects and criticality analysis" and "Toxicological risk evaluation", but their defect - limited use for risk evaluation either on danger or on harmful production factors - makes it impossible to use any of them as a recommended complex method for the evaluation stage. Thus, the identified defects did not identify the selection any of the mentioned methods as an objective basis for a complexity of the risk evaluation stage in occupational health and safety. This is due to the fact that the developers of the IEC/ISO 31010:2019 standard tried to make it as universal as possible for all activities where risk evaluation is required. In this case, the search for universality has a negative impact on the quality of the standard content, which (like the previous one) is pro forma. The existing methodological support is presented in a general form and is not specified by the final result (mathematical model, calculation formula, and so on). This leads to the fact that in practice for a complex risk evaluation in occupational health and safety implementors select only expert methods, which are presented in the standards in the most understandable form [14]. These methods are generally recommended for using by training centers to certify enterprise based on OHSAS and ISO 45001:2018 standard. And although the possibility of their complex application is allowed by the SA and A criteria, still the objectivity and practical value of such application remains a major challenge [14].

Instead, the known methods of mathematical modeling of random processes are given in IEC/ISO 31010:2019 in a limited form and are not in the list of the recommended ones for complex risk evaluation not only by criterion SA but even A [14]. However, just on the basis of these methods it is possible to develop methodological support for the complex implementation of the evaluation stage, which will take into account all the objective features (random, dynamic characteristics, and so on) of negative NF impact on the employee, within the "man-machine-environment" system [20]. In addition, the use of appropriate mathematical tools allows developing a PC software, which greatly simplifies the use of methodological support in organizations. In order to address the identified defects, there is a need to improve the standard IEC/ISO 31010:2019 by adding the relevant methodological support into its content and structure for the following: the possibility of implementing the stage of determining of resources; ensuring the principle of complexity of the risk evaluation stage, as well as increasing the objectivity of its results. Given that this methodological support should be added directly into the information appendix B, its submission involves compliance with the relevant structure [14]. Namely: Overview, Use, Inputs, Outputs, Strengths and limitations, Reference document [14]. In addition, given the need to address the general problem of the order of the implementation of the planning procedure stages, it is appropriate to improve the structure of Table A. 3 for occupational health and safety and describe it as [14].

As shown, the related position on the selection of method for the stage of Determination of resources by the criterion of applicability (A, SA, NA, etc.) is added to the structure of Table (in contrast to the existing version of Table A.3). The Risk identification stage is separated from the Risk assessment process stage and together with the Determination of resources stage precedes it. In turn, now the assessment stage involves only two sub-steps: Risk analysis and Risk evaluation. Thus, the application of methodological support is proposed for the stage of Determination of resources, which is developed on the basis of convex optimization methods [14]. The methodological support was tested in the occupational health and safety management system of the company "Stalkanat-Silur", as well as in the Social Insurance Fund of Ukraine. Based on the results of its development, an intellectual copyright certificate was obtained (No. 92945) [12].

Overview. Methodological support is aimed at determining the optimal resources for the development, implementa-

Improved structure of Table A3 of IEC 31010:2019 standard

\begin{tabular}{|c|c|c|c|c|c|c|c|}
\hline \multirow{3}{*}{$\begin{array}{l}\text { Tools and } \\
\text { techniques }\end{array}$} & \multirow{3}{*}{$\begin{array}{c}\text { Risk } \\
\text { identification }\end{array}$} & \multirow{3}{*}{$\begin{array}{l}\text { Determination of } \\
\text { resources }\end{array}$} & \multicolumn{4}{|c|}{ Risk assessment process } & \multirow{3}{*}{ Sub-clause } \\
\hline & & & \multicolumn{3}{|c|}{ Risk analysis } & \multirow{2}{*}{$\begin{array}{c}\text { Risk } \\
\text { evaluation }\end{array}$} & \\
\hline & & & Consequence & Likelihood & Level of risk & & \\
\hline
\end{tabular}


tion and operation of a set of activities and means for occupational health and safety while limiting the set risk level (direct task). In mathematical form, the direct task is defined as the problem of minimizing the function [12]

$$
\bar{B}(\vec{H})=\sum_{i=1}^{n}\left[H_{i}+p_{i} g_{i}\left(h_{i}+H_{i}\right)^{-j_{i}}\right],
$$

if

$$
1-\prod_{i=1}^{n} F_{i}\left(k_{i} / T\right) \leq r
$$

where $\vec{H}=\left(H_{1}, \ldots, H_{n}\right), H_{i}$ are resources to eliminate the impact of the $i^{\text {th }}$ type of identified NF; $p_{i}$ - the cost of eliminating the unit of consequences of the negative impact of NF on the employee; $g_{i}, j_{i}-$ data on the actual excess of normalized values at appropriate costs allocated to activities and means of occupational health and safety; $h_{i}$ - the cost of compensation for harm to health, due to the impossibility of complete elimination of the negative impact on the employee of the $i^{\text {th }}$ factor; $F_{i}(y)$ - the distribution function of the random variable; $\alpha_{i}-$ the intensity of the negative impact of the $i^{\text {th }}$ factor on the employee; $k_{i}$ - the normalized value of the $i^{t h}$ factor; $T$ - the time during which an employee has a negative impact of the $i^{\text {th }}$ type of NF with random intensity $\alpha_{i} ; r-$ (acceptable) risk level set by the organization.

Methodological support also allows solving the reverse task, which can be presented as maximizing the level of occupational safety of the employee while limiting the resources for occupational health and safety. In this case, the level of occupational safety is expressed as the probability of non-occurrence of any dangerous event according to a certain nomenclature of identified NF. In mathematical form, this task is defined as the maximization of the function [12]

$$
\mathrm{P}(\vec{H})=\prod_{i=1}^{n} F_{i}\left(k_{i} / T\right)
$$

if

$$
\sum_{i=1}^{n}\left[H_{i}+p_{i} g_{i}\left(h_{i}+H_{i}\right)^{-j_{i}}\right] \leq \Phi,
$$

where $\Phi$ is the amount of the financial resources of the organization for occupational health and safety during the time $T$.

Use. It is used in the implementation of the planning procedure at the stage of determining the resources for occupational health and safety (by the SA criterion).

Inputs (for direct and reverse tasks). Information concerning: nomenclature of identified NF for each workplace; normalized values of identified NF; the resources provided by the organization for organizational and technical preventive safety activities and means, elimination of the consequences of the implementation of the risk to occupational danger, as well as compensation for harm to the employee's health; the value of the risk level, set by the organization.

Outputs. Quantitative results on the minimum possible resources for the activities and means of occupational health and safety, which would not exceed the risk level, set by the organization, taking into account the random impact of the NF on the employee during the work shift (direct task). Quantitative results on the risk level that will not be exceeded with a certain resources for occupational health and safety, set by organization (reverse task). Documented information on the obtained quantitative results (according to the requirements of paragraph 7.5) [11]

Strengths and limitations. The main strengths of the methodological support are: the possibility of its use in all organizations without exception, since the information collected and processed within the existing $\mathrm{HC}$ and OSS systems is used as the inputs; the possibility of calculations using the standard PC package Microsoft Excel (option "Solution Search"); tak- ing into account the random characteristics of the impact of negative factors on the employee; the possibility of calculations for different distribution of a random variable (according to the requirements of par. 6.3.5.1) [14]; the possibility of redistribution of resources for occupational health and safety in the direction of more significant risks (according to the nomenclature of identified NF); compliance with the conditions of selection of the SA criterion. The main limitations are impossibility to take into account the dynamic characteristics of the negative impact of NF on the employee, as well as the need for having competencies for the implementor to use the Microsoft Excel software package.

Reference document. An example of solving problems $(2-5)$ is given in [12].

To comprehensively implement the risk assessment stage (in relation to the defined nomenclature of identified NF and by SA criteria), as well as to increase the objectification of its results, it is proposed to use methodological support developed on the basis of a special apparatus of Markov processes drift processes. Methodological support has been tested in the management system of occupational health and safety of the company "Stalkanat-Silur". According to the results, an intellectual copyright certificate was obtained (No. 92946) [20].

It should be noted that the standard IEC/ISO 31010:2019 already contains methodological support (par. B 5.9 - Markov analysis), which is developed on the basis of the theory of Markov processes [14]. However, in contrast to the one proposed below, the existing method provides using Markov chains for the risks evaluation, which allows considering tasks only under the conditions of the given amount of states and continuous time [14]. Such conditions do not comply with real (dynamic and random in time) characteristics of the impact of NF on the employee, therefore the results of risk evaluation cannot be as objective [20].

Overview. The proposed methodological support allows determining the probability of occupational dangers associated with the negative impact on the employee, both dangerous and harmful production factors. In the latter case, it is possible to determine both the probability that the level of negative impact of HPF on employee exceeds normalized values, and the average level of accumulation of the certain negative impact, according to sanitary legislation, both in Ukraine and in EU and US countries. In this case, the methodological support takes into account the real characteristics of the impact of HPF on the employee, when during the work shift (but in random periods of time) the consequences of such impact is accumulated in the body, and after hours are excreted. The relevant characteristics of the negative impact of dangerous production factors, when such impact occurs instantly in a random period during the work shift, are also taken into account. In this case, the severity of the consequences of the injury is determined by the recovery time (treatment) of the employee. The risk evaluation stage involves a preliminary solution of the differential equations system (analytically or with the help of the Matlab software package) and the definition of the following indicators [20]:

- the probability that the accumulation level of the HPF impact on the employee exceeds normalized values

$$
\begin{aligned}
& \int_{0}^{\infty}\left(q_{00}^{-}(\tau)+q_{01}^{-}(\tau)\right)\left(1-A_{0}(\tau)\right) d \tau+ \\
& +\int_{0}^{\infty}\left(q_{11}^{-}(\tau)+q_{12}^{-}(\tau)\right)\left(1-A_{1}(\tau)\right) d \tau,
\end{aligned}
$$

where $\tau$ is the time between the beginning of the work shift (the beginning of non-working hours) and the moment $t ; x$ is the amount of harmful substances on the employee at time $t$;

$q_{i k}(x, \tau), q_{i k}^{-}(\tau)$ - the density of the probability of joint distribution of the amount of harmful substances and the time remaining before the change of the alternating process state $A$ $(I=0,1 ; k=1,2)$; 
- the average level of accumulation of the HPF impact on the employee

$$
\begin{aligned}
\mathbf{M} \xi & =\int_{0}^{\infty} x \int_{0}^{\infty}\left[\left(q_{00}(x, \tau)+q_{01}(x, \tau)+q_{02}(x, \tau)\right)\left(1-A_{0}(\tau)\right)+\right. \\
& \left.+\left(q_{10}(x, \tau)+q_{11}(x, \tau)+q_{12}(x, \tau)\right)\left(1-A_{1}(\tau)\right)\right] d \tau d x,
\end{aligned}
$$

where $\xi$ - the level of accumulation of the HPF impact on the employee;

- the probability of the occupational injury in a random period of time (during the work shift) by the employee

$$
\begin{gathered}
\left.\int_{0}^{\infty} q_{12}^{-}(\tau)\right)\left(1-A_{1}(\tau)\right) d \tau+\int_{0}^{\infty} \int_{0}^{\infty}\left[q_{02}(x, \tau)\left(1-A_{0}(\tau)\right)+\right. \\
\left.\left.+q_{12}(x, \tau)\right)\left(1-A_{1}(\tau)\right)\right] d x d \tau .
\end{gathered}
$$

Use. It is used for comprehensive implementation of the risk assessment stage (substages of Risk analysis and Risk evaluation) by the SA criterion.

Inputs (to find probabilities 6-8). Information concerning: nomenclature of identified NF for each workplace; normalized values of each identified NF; the density of the HPF impact on the employee; the density of equipment failure that led to the injury of the employee (determined by processing statistical data), the recovery time of the employee after injury (treatment and rehabilitation).

Outputs. Quantitative results on the probability of an employee's occupational injury in a random period, the probability that the accumulation level of the HPF impact on the employee exceeds normalized values in a random period, the average level of accumulation in the body of negative consequences of HPF, the probability that in a random period the consequences of HPF in the body are absent. Documented information on the obtained quantitative results (according to the requirements of par. 7.5) [11].

Strengths and limitations. The main advantages of methodological support are: taking into account the real characteristics of the dynamic random NF impact on the employee, and the possibility of obtaining objective evaluation results; the possibility to assess external factors that could negatively affect the employee's safety (for example, certain environmental factors); comprehensiveness of using (by the SA criterion) for all sub-stages of the evaluation stage (in contrast to B 5.2, B 5.3, B 5.9, B 5.10 and other methods of mathematical modeling) [14]; the possibility to obtain quantitative evaluation results, both through the Matlab software package and analytically. The main limitations are the significant time on obtaining evaluation results using an analytical approach; the need to have special competencies to use the Matlab software package.

Recommended Books. An analytical way to solve the differential equations system to obtain the required probabilities $(6-8)$ is given in [20].

Thus, the integration of the proposed methodological support into the content and structure of the information appendix B allows solving current problems of normative legal support associated with the impossibility of objective implementation of the stages of determining of resources and risk evaluation. At the same time, it should be noted that in practice, for the stage of determining of resources the solving the reverse task is more current (4), because the resources for occupational health and safety are always limited by budget policy, and the risk level of occupational dangers (as a criterion) is not defined by ISO standards or any national legislation of the world. However, in terms of the efficiency of $\mathrm{HC}$ and OSS systems, setting limits for organizations at the legislative level which does not exceed certain risk levels (by industry) would minimize the problem of formal implementation of both the relevant stage of the Plan procedure and the PDCA process [2]. However, regardless of the selected task, the purpose of this stage is always to find a compromise between the profitability of the organization and its resource capabilities to ensure max- imum safety of the employee. Achieving a compromise is determined by the value of an acceptable risk level $-r(3)$, which characterizes, relatively, the limitations of the organization (to ensure the maximum level of occupational safety) beyond which the reason for its being becomes economically sensible. Based on this, the level of acceptable risk, in fact, becomes the objective criterion that needs to be compared with the results of quantitative risk evaluation $\left(r_{0}\right)$ obtained during the analysis sub-step. This comparison takes place within the Risk evaluation sub-stage and accordingly provides for the implementation of the following condition

$$
r_{0} \leq r .
$$

This expression can be considered correct, because in the development of methodological support, both for the stage of determining of resources and for the stage of risk assessment $(2-8)$ the condition (1) was taken into account. Therefore, given that the controlled parameters for models (6-8) are the intensity of the NF impact on the employee, the task of the risk assessment stage is the need to set such values of controlled parameters that will ensure (according to the definition $r_{0}$ ) condition (9) [20]. The result of condition (9) indicates that the planning procedure can be considered successfully completed. The above statement of the evaluation task allows one not only to set the existing relationships between the Plan procedure stages and clearly understand the purposes and results of their implementation, but also to understand the order, requirements and opportunities for next procedures of PDCA process. Because the lack (as shown in the analysis results) of a clear understanding of the purposes, results and opportunities (methodological, practical, etc.) of certain stages and procedures was the reason of window dressing (actual helplessness) of ISO 45001:2018 content (as OHSAS) and, accordingly, the low methodological and practical value of the existing PDCA concept for HC and OSS systems. Thus, the need to implement (9) enables not only to eliminate certain defects of the normative legal support of the PDCA process, but also to start a new concept for its implementation, which fundamentally differ from the existing one (according to ISO 45001:2018). The difference is to provide conditions for direct (if possible) management of the parameters of the negative impact of the identified NF on the employee within the set values. This approach involves the use of activities of continuous monitoring and prompt correcting of the parameters of the certain NF, which will ensure the implementation (9) within the "Do - Check - Act" procedures. The use of these activities is necessary considering random (requires constant monitoring) and dynamic (requires prompt correcting) nature of changes in the parameters of the intensity of the NF impact on the employee over time. That is, the proposed PDCA concept provides for the implementation of the principles of proactive management (prevention of incidents, by continuous monitoring and prompt correcting of certain parameters), and the existing one is based on the so-called semi-active principle (when measuring parameters can occur not constantly and not necessarily, but the correcting ones is only a reaction to an incident that has already taken place) (par. 9.1.1) [11]. Thus, the new concept of proactive management can be presented as an improved PDCA process (Fig. 2). At the same time, within the given process it is possible to consider two separate (small) cycles. The first of them (conventionally - methodological) occurs within the Plan procedure between its three stages, whose result is the setting of values of controlled parameters (for each identified NF), ensuring the condition (9). If condition (9) is not met, the small cycle begins again. After its implementation it is possible to pass to the next procedure - Do, whose task is to provide not exceeding of the set values of the controlled parameters. If within this procedure the values of controlled parameters are maintained within the set limits (according to the results of their constant monitoring), the PDCA 
process can occur on the second (conventionally - practical) small cycle "Check - Act" (within the Do procedure) (Fig. 2). In case of impossibility of the corresponding correcting or in case of occurrence of incident, PDCA process begins from the beginning of the Plan procedure (Fig. 3).

However, the implementation of the new proactive PDCA concept has some caveats related to the existence of the following main problem (as for the existing concept) - the principles of active management can be applied (so far) only to a limited nomenclature of NF (usually for a number of HPF). The complexity of this problem involves two ways of its solution. The first is that not all NF have normalized values to date. And the second is that for the rest of the NF the normalized values cannot be set at all. Accordingly, the values of controlled parameters can be objectively set (during evaluation) not for all NF.

The first way of solving the problem involves the need to develop appropriate normalized values for a number of NF, that should be instrumentally measured or to develop objective approaches to normalize them by secondary signs [17]. This way is valid for certain HPF, whose normalized values are absent to date. However, this problem is quite global and requires joint action of specialists from different fields of science and government institutions. The second way of solving the problem concerns the provision of objective opportunities to manage the parameters of the impact of such NF, as the "human factor" signs, certain factors of the psychophysiological group, some dangerous production factors. In turn, the solution of the problem in this way should also be considered under two aspects. For example, management parameters for certain NF (some dangerous production) can be determined by processing statistics. This practice is widely used in the tasks of reliability theory to determine the failure intensity of equipment. And although the values for such parameters can be set during the evaluation, but active management of them is impossible. For other parameters of the NF impact (the "human factor" signs, and others) it is impossible either to set appropriate values or to use the traditional principles of active management. Therefore, based on the principles of the new concept, certain hybrid (direct and indirect) management principles (the author's definition) should be used to such NF, which consist in the using of a system of interrelated controlling and enforcing activities and means. In practical terms, this main problem can be solved by using automated system of comprehensive protection of employees from occupational dangers (Ukrainian patent for invention No. 118077) in HC and OSS systems of organizations. The automated system contains certain conditional units aimed at managing the sanitary and hygienic parameters of the production environment, the parameters of the movement of intra-shop transport, the parameters of monitoring the condition of dangerous areas, minimizing the "human factor" signs and others. For example, to minimize the impact of

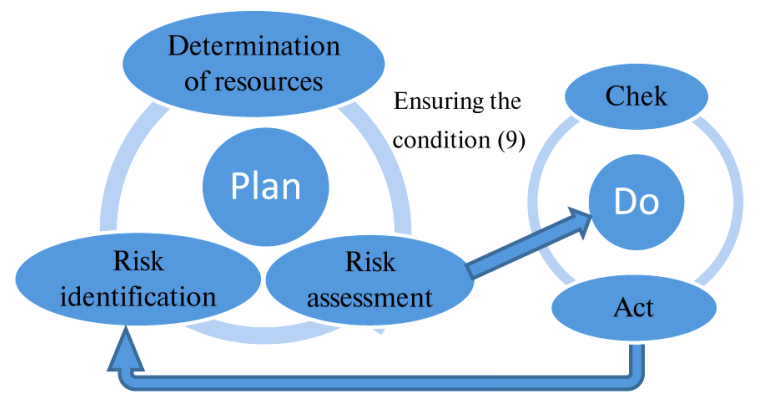

In case of occurrence of incident or in case of impossibility of the correcting parameters within the set values negative "human factor" signs, the automated means to control and test knowledge of occupational health and safety before work shift (constant control), to limit access to the workplace with inappropriate test results (operational correcting), the permanent video control of workplaces with dangerous working conditions with the possibility of prompt response to occurrence of danger (dangerous actions/inactions of employee) and others are provided. The principles of building and operation of the automated system provide its using in $\mathrm{HC}$ and OSS systems for procedures "Do - Check - Act", therefore they can be used as a basis for developing an algorithm of relevant procedures and requirements for obtaining final results of their implementation within relevant sections of standards ISO 45001:2018 and ISO 31000:2018. In addition, the automated system allows storing data concerning the values of controlled parameters for each workplace during the work shift and in a certain period, recording incidents, controlling the procedure and order for obligatory medical examinations, performing other functions and providing information for analysis and audit of the effectiveness of HC and OSS systems (in particular according to par. 7.5 and par. 9 of ISO 45001:2018, as well as par. 6.7 of ISO 31000:2018).

\section{Conclusions.}

1. Based on the results of the analysis of the content and structure of ISO 45001:2018, it is set that the main problem that prevents the objective implementation of the PDCA process within the $\mathrm{HC}$ and OSS systems is the uncertainty of the standard requirements for purposes, order and results of each procedure. This problem is exacerbated by the absence of any references in the standard to the necessary normative legal documents, within the requirements of which its solution would be possible.

As preconditions for the development of ways for solving the main problem, the necessity is substantiated for the following:

- considering the Plan procedure as a set of three sequential stages - NF identification, determination of resources for occupational health and safety and risk evaluation;

- defining the task of implementing the stage of determining resources, as the task of setting the relationship between the resources for occupation health and safety and the risk level;

- using the results of the Plan procedure as the values of the controlled parameters for the implementation of the Do procedure;

- implementing continuous monitoring and prompt correcting of the values of the certain controlled parameters within the Check and Act procedures.

The ways of solving the main problem are the need to determine the methodological support for the objective implementation of each stage of the Plan procedure and to provide practical opportunities for the implementation of Do Check - Act procedures in accordance with these preconditions.

2. The analysis of IEC/ISO 31010:2019 showed that within the proposed methodological support the objective implementation of the Plan procedure is impossible, that is explained by the following main problems: lack of methods for implementing the stage of determining of resources; the impossibility of comprehensive implementation of the risk evaluation stage (under condition the application of the SA criterion) within a separate method; the impossibility of taking into account the real (random and dynamic) characteristics of the NF impact on the employee (during risk evaluation). Problems that do not directly influence the possibility of implementing the Plan procedure, but influence the objectivity of its results (at the identification stage) should be stressed. These include: the impact of the "human factor" signs (on the identification results), which is due to the need to use expert methods to perform this stage; the absence of a certain nomenclature of classified negative factors and set normalized values for 
a significant number of such factors (both in the national legislation of most countries of the world and in the system of standards of the ISO series).

3. For the objective implementation of the Plan procedure, methodological support for the stages of determining of resources and risk evaluation, which allows determining, respectively: the optimal resources for development, implementation and ensuring of the complex activities and means of occupational health and safety with limitation to an acceptable risk level; the probability of sustaining an occupational injury by an employee in a random period, exceeding the level of accumulation in the employee of the HPF impact to normalized values and other indicators of occupational safety were proposed for use in IEC/ISO 31010:2019. It is set that the Plan procedure is considered to be successfully completed provided that the quantitative result of the risk level evaluation $r_{0}$ (for each identified factor) does not exceed the appropriate level of acceptable risk $r$ set by the organization (at the stage of determining resources). Given that the controlled parameters within the proposed methodological support for risk evaluation are the intensity of the NF impact on the employee, the task of the risk evaluation stage is presented as the task of setting such values of controlled parameters that allow ensuring the condition $r_{0} \leq r$.

4. The above statement of the task of the risk evaluation stage allows proposing a new concept of implementation of the PDCA process, consisting of two small cycles - methodological and practical. The first cycle determines the nomenclature and values of controlled parameters (according to the nomenclature of identified NF and condition (9)), and the second one ensures that such values should not be exceeded to maintain safe, healthy and comfortable working conditions in each workplace. The transition of HC and OSS systems to the new concept will provide: the possibility of applying the principles of active management of occupational health and safety; the existence of objective relationships between all procedures of the PDCA process, which in turn solves the problem of uncertainty of the requirements of ISO 45001:2018 concerning purposes, order and results of its implementation; improving the efficiency of $\mathrm{HC}$ and OSS systems, by providing the ability to manage certain parameters of the NF impact on the employee; setting clear causation between the parameters of the NF impact on the employee and the incident (based on the analysis of the dynamics of the NF impact over time), which allows objectifying the results of the investigation and preventive activities to prevent further its occurrence; reduction of the organization's costs for occupational health and safety, by eliminating the need to implement the Plan procedure regularly, as well as other benefits.

5 . The main problem with the introduction of a new concept of the PDCA process in HC and OSS systems is that the principles of active management can be applied (so far) only to a limited nomenclature of NF (usually for HPF). The complexity of this problem involves consideration of two ways of its solution. The first way involves the need to develop appropriate normalized values for a number of NF, which should be instrumentally measured or to develop objective approaches to normalize them by secondary signs (promising way of further research). The second way concerns the provision of objective opportunities to manage the parameters of the impact of such NF, as "human factor" signs, certain factors of the psychophysiological group, some dangerous production factors. To ensure these opportunities, the use of hybrid (direct and indirect) management principles, which consist in the application of a system of interconnected controlling and enforcing activities and means, was proposed. In practical terms, this main problem can be solved by using automated system of comprehensive protection of employees from occupational dangers (Ukrainian patent for invention No.118077) in HC and OSS systems of organizations.

\section{References.}

1. Bochkovskyi, A.P., Sapozhnikova, N.Yu., \& Gogunskii, V. D. (2017). Legal and organizational issues of improving the labor protection and industrial safety level at Ukrainian enterprises. Naukovyi Visnyk Natsionalnoho Hirnychoho Universytetu, (5), 100-108.

2. Bochkovskyi, A.P. (2018). Actualization of the scientific principles elaboration on evaluating the risks of occupational danger occurrence. Naukovyi Visnyk Natsionalnoho Hirnychoho Universytetu, (6), 95-103. https://doi.org/10.29202/nvn$\mathrm{gu} / 2018-6 / 14$.

3. ISO 45001 - All you need to know (2020). Retrieved from https://www.iso.org/ru/news/ref2271.html.

4. ISO 31000 Risk management (2020). Retrieved from https:// www.iso.org/iso-31000-risk-management.html.

5. Karkoszka, T. (2017). Operational monitoring in the technological process in the aspect of occupational risk. Procedia Manufacturing, 13, 1463-1469. https://doi.org/10.1016/j. promfg.2017.09.192.

6. Skład, A. (2019). Assessing the impact of processes on the Occupational Safety and Health Management System's effectiveness using the fuzzy cognitive maps approach. Safety Science, 117, 71-80. https://doi.org/10.1016/j.ssci.2019.03.021.

7. Philip P. Purpura (2019). Safety in the Workplace. Security and Loss Prevention (Seventh Edition), 435-455. https://doi. org/10.1016/B978-0-12-811795-8.00014-X.

8. Rosa Anaya-Aguilar, Manuel Suárez-Cebador, Juan Carlos Rubio-Romero, \& Fuensanta Galindo-Reyes (2018). Delphi assessment of occupational hazards in the wineries of Andalusia, in southern Spain. Journal of Cleaner Production, 196, 297-303. https://doi.org/10.1016/j.jclepro.2018.06.008.

9. Serenay Çalış, \& Banu Yeşim Büyükakıncı (2019). Occupational health and safety management systems applications and a system planning model. Procedia Computer Science, 158 , 1058-1066. https://doi.org/10.1016/j.procs.2019.09.147.

10. Iñaki Heras-Saizarbitoria, Olivier Boiral, German Arana, \& Erlantz Allur (2019). OHSAS 18001 certification and work accidents: Shedding light on the connection. Journal of Safety Research, 68, 33-40. https://doi.org/10.1016/j.jsr.2018.11.003. 11. ISO 45001:2018. Occupational health and safety management systems - Requirements with guidance for use (n.d.). Retrieved from https://www.iso.org/obp/ui/\#iso:std:iso:45001:ed-1:v1:en. 12. Bochkovskii, A. P., \& Gogunskii, V. D. (2018). Development of the method for the optimal management of occupational risks, Eastern-European Journal of Enterprise Technologies, 3/3(93), 6-13. https://doi.org/10.15587/1729-4061.2018.132596. 13. ISO 31000:2018. Risk management - Guidelines (n.d.). Retrieved fromhttps://www.iso.org/obp/ui/\#iso:std:iso:31000:ed2:v1:en.

14. IEC 31010:2019. Risk management - Risk assessment techniques (n.d.). Retrieved from https://www.iso.org/obp/ ui/\#iso:std:iec:31010:ed-2:v1:en,fr.

15. European Agency for Safety and Health at Work. Hazard identification checklist: occupational safety and health issues associated with green building (n.d.). Retrieved from https://pdfs. semanticscholar.org/6e 4c/e 2f3fc 7d 57adc03cf8aaabbfd2960a17101c.pdf.

16. The Occupational Safety and Health Administration is Finland: working conditions (2020). Retrieved from https://www. tyosuojelu.fi/web/en/working-conditions.

17. European Agency for Safety and Health at Work. European directives on safety and health at work (2020). Retrieved from https://osha.europa.eu/ru/safety-and-health-legislation/european-directives.

18. European Agency for Safety and Health at Work. Exposure to chemical agents and chemical safety (2020). Retrieved from https://osha.europa.eu/en/legislation/directives/exposureto-chemical-agents-and-chemical-safety/.

19. Magne Bråtveit, Rune Djurhuus, Jorunn Kirkeleit, \& Bjørg Eli Hollund (2018). Health risks and prevention practices during handling of fumigated containers in ports. Luxembourg: 
Publications Office of the European Union. Retrieved from https://www.idit.fr/infonews/documents/news-31037-OSHfumigated-containers.pdf.

20. Bochkovskyi, A. (2019). Development of stochastic models for occupational hazards risk assessment. Bulletin of Lviv State University of Life Safety, 19, 68-78. https://doi.org/10.32 447/20784643.19.2019.07.

\section{Удосконалення принципів управління ризиками у сфері охорони праці}

\section{А. П. Бочковський}

Одеський національний політехнічний університет, м. Одеса, Україна, e-mail: andrew.bochkovsky@gmail.com

Мета. Удосконалити принципи управління ризиками у сфері охорони праці.

Методика. У рамках дослідження застосовувався наступний комплекс наукових методів: аналіз науковотехнічної літератури й міжнародних нормативно-правових документів щодо побудови та функціонування систем управління охороною праці; імовірнісно-статистичні методи; теорія марківських процесів; методи формалізації.

Результати. Визначені основні проблеми, що унеможливлюють об'єктивну реалізацію процесу PDCA в рамках функціонування сучасних систем управління охороною праці в організаціях. Зазначено, що виявлені проблеми пов'язані 3: невизначеністю вимог ISO 45001:2018 щодо цілей, порядку й результатів виконання кожної з процедур процесу PDCA у сфері охорони праці; недосконалістю методичного забезпечення основних етапів процедури Plan; відсутністю практичних можливостей для об'єктивної реалізації процедур Do, Check, Act. Встановлені передумови для переходу систем охорони здоров'я (O3) та забезпечення безпеки праці (ЗБП) до нової концепції проактивного управління ризиками (на основі функціонування двох малих циклів у рамках реалізації процесу PDCA), що дозволяє забезпечити: наявність об'єктивних взаємозв'язків між усіма процедурами процесу PDCA; підвищення ефективності функціонування систем О3 і ЗБП за рахунок забезпечення можливості керування окремими параметрами впливу негативних факторів на працівника; встановлення чітких причинно-наслідкових взаємозв'язків між параметрами впливу негативних факторів на працівника та інцидентом, а також інші переваги. Обгрунтована можливість застосування автоматизованої системи комплексного захисту працюючих від професійних небезпек задля вирішення практичних проблем реалізації нової концепції РDCA в системах О3 і ЗБП організацій.

Наукова новизна. Уперше обгрунтована та запропонована до застосування в системах О3 і ЗБП концепція проактивного управління ризиками, що базується на принципах функціонування малих циклів у рамках реалізації процесу PDCA.

Практична значимість. Отримані результати будуть використані для розробки проектів змін змісту та структури міжнародних стандартів ISO 45001:2018, IEC/ISO 31010:2019, ISO 31000:2018.
Ключові слова: охорона праці, иикл Шухарта-Демінга, управління ризиками, ISO 45001:2018

\section{Усовершенствование принципов управления рисками в сфере охраны труда}

\section{А. П. Бочковский}

Одесский национальный политехнический университет, г. Одесса, Украина, e-mail: andrew.bochkovsky@gmail.com

Цель. Усовершенствование принципов управления рисками в сфере охраны труда.

Методика. В рамках исследования применялся следующий комплекс научных методов: анализ научно-технической литературы и международных нормативно-правовых документов в сфере создания и функционирования систем управления охраной труда; вероятностностатистические методы; теория марковских процессов; методы формализации.

Результаты. Определены основные проблемы, препятствующие объективной реализации процесса PDCA в рамках функционирования современных систем управления охраной труда в организациях. Установлено, что выявленные проблемы связаны с: неопределенностью требований ISO 45001:2018 относительно целей, порядка и результатов выполнения каждой из процедур процесса PDCA в сфере охраны труда; несовершенством методического обеспечения основных этапов процедуры Plan; отсутствием практических возможностей для объективной реализации процедур Do, Check, Act. Определены предпосылки для перехода систем охраны здоровья (O3) и обеспечения безопасности труда (ОБТ) к новой концепции проактивного управления рисками (на основе функционирования двух малых циклов в рамках реализации процесса PDCA), что позволяет обеспечить: наличие объективных взаимосвязей между всеми процедурами процесса PDCA; повышение эффективности функционирования систем ОЗ и ОБТ за счет обеспечения возможности управления отдельными параметрами влияния негативных факторов на работника; установление четких причинноследственных взаимосвязей между параметрами влияния негативных факторов на работника и инцидентом, а также другие преимущества. Обоснована возможность применения автоматизированной системы комплексной защиты работающих от профессиональных опасностей для решения практических проблем реализации новой концепции PDCA в системах О3 и ОБТ организаций.

Научная новизна. Впервые обоснована и предложена к применению в системах О3 и ОБТ концепция проактивного управления рисками, которая базируется на принципах функционирования двух малых циклов в рамках реализации процесса PDCA.

Практическая значимость. Полученные результаты будут использованы для разработки проектов изменений содержания и структуры международных стандартов ISO 45001:2018, IEC/ISO 31010:2019, ISO 31000:2018.

Ключевые слова: охрана труда, иикл Шухарта-Деминга, управление рисками, ISO 45001:2018

Recommended for publication by V.E. Volkov, Doctor of Technical Sciences. The manuscript was submitted 15.11.19. 